\title{
Dara além da fronteira \\ UMA LEITURA DO ROMANCE ESTIVE EM LISBOA E LEMBREI DE VOCÊ, DE LUIZ RUFFATO, SOB A ÓTICA PÓS-MODERNISTA
}

Beyond the frontier: a reading of the novel "Estive em Lisboa e Lembrei de Você", by Luiz Ruffato, from a post-modernist perspective

\section{Keiliane da Silva Araújo Carvalho}

Resumo: Na pós-modernidade, a literatura, numa esfera global, tem passado por mudanças substanciais. Conforme explica Jean-François Lyotard (2002), o pós-moderno configura-se como o estado em que a cultura se encontra após as transformações que modificaram as regras dos jogos circunscritos à ciência, à literatura e às artes, a contar do século XIX. Nesse sentido, a lógica pós-moderna se insere sob um sistema diverso, multifacetado, promovendo, assim, a desestabilização do que Zygmunt Bauman (1998) nomina de "tempo-espaço" firme, durável. Partindo dessa acepção, este trabalho propõe uma análise de Estive em Lisboa e Lembrei de Você (2009), do escritor contemporâneo Luiz Ruffato, à luz de uma perspectiva pós-modernista. A prosa referida é narrada por Sérgio de Sousa Sampaio. Este, a partir de um discurso trivial, mas frenético, que, além do falar mineiro, subjaz à própria velocidade comum ao lócus urbano, conta as suas aventuras "arrivistas" (BAUMAN, 1998) em espaços demasiado díspares, a saber: Cataguases, Minas Gerais, e Lisboa, Portugal. A fim de sustentar os aspectos percebidos e evidenciados ao longo do estudo, as teorizações formuladas por Jean-François Lyotard (2002); Fredric Jameson (1982; 1984); Zygmunt Bauman (1998; 2005; 2008); David Harvey (1996); Leyla Perrone-Moisés (2016); entre outros, servem como base de fundamentação.

Palavras-chave: Pós-modernidade; Romance pós-moderno; Luiz Ruffato.

Abstract: In postmodernity, literature has undergone substantial changes in a global sphere. As Jean-François Lyotard (2002) explains, from the 19th century onwards, the postmodern is the state in which culture finds itself after the transformations that changed the rules regarding science, literature and arts. In this sense, postmodern logic is located under a diverse, multifaceted system, thus promoting the destabilization of what Zygmunt Bauman (1998) calls firm, durable "time and space". Based on this, this article aims to analyze the novel Estive em Lisboa e Lembrei de Você (2009), by contemporary writer Luiz Ruffato, through a postmodernist perspective. The story under analysis is narrated by Sérgio de Sousa Sampaio. From a trivial but

1 Mestranda em Literatura pelo Programa de Pós-Graduação da Universidade Estadual do Piauí (UESPI). Graduada em Letras/Português pela Universidade Estadual do Maranhão (UEMA). E-mail: araujokeiliane44@gmail.com. 
frantic discourse, which, in addition to the language spoken in Minas Gerais, conceals even the speed common to that urban location, the character tells his "upstart" adventures (BAUMAN, 1998) in quite different spaces, such as: Cataguases, Minas Gerais, and Lisbon, Portugal. In order to support the aspects observed and highlighted throughout the study, the theories traced by Jean-François Lyotard (2002); Fredric Jameson (1982; 1984); Zygmunt Bauman (1998; 2005; 2008); David Harvey (1996); Leyla Perrone-Moisés (2016); and others, serve as a basis.

Keywords: Postmodernity; Postmodern Novel; Luiz Ruffato.

\section{consideracões iniciais}

O ponto de partida do estudo que se segue é o de evidenciar como os aspectos da pós-modernidade se apresentam em Estive em Lisboa e Lembrei de Você (2009), de Luiz Ruffato, escritor que, assim como João Gilberto Noll, Milton Hatoum, Nélida Piñon, Lya Luft, Murilo Rubião, Dalton Trevisan, Ferreira Gullar, entre outros, emerge no cenário brasileiro como antagônico aos moldes pré-estabelecidos, dando forma à literatura contemporânea.

A dialética da pós-modernidade, é lúcido afirmar, se inscreve de maneira ampla e conflituosa tendo em vista os vários cognatos que circunscrevem o termo - pós-moderno, sociedade pós-industrial, modernidade-líquida, supermodernidade, sociedade da informação etc., discutidos por autores como Fredric Jameson (1982; 1984), Zygmunt Bauman (1998; 2008), Terry Eagleton (1998), entre outros - e as inúmeras perspectivas, diferenciações ou similitudes creditadas a cada um. Entretanto, o objetivo aqui empreendido não é o de traçar um panorama histórico desses epítetos e, tampouco, das especificidades que os cercam, visto que, ao tentar fazê-lo, a discussão se estenderia e caminharia para um ermo de laborações eternamente cíclicas. Para além disso, faz-se necessário avultar a noção de pós-modernidade e, paralelamente, tentar suscitar o entendimento do período que o antecede, a modernidade, não como conceitos ontológicos, fechados, demarcados, mas como aglomerados simbólicos que se constituem de preceitos múltiplos, porque abarcam questões diversas, tais como: culturais, artísticas, tecnológicas, econômicas, entre outras.

Jameson (1984), uma das grandes vozes autorizadas no que toca à temática da pós-modernidade, tendo desenvolvido seus estudos sob um viés 
epistemológico interdisciplinar, explica que os últimos tempos têm sido marcados "por um milenarismo invertido segundo o qual os prognósticos, catastróficos ou redencionistas, a respeito do futuro foram substituídos pelo fim disto ou daquilo" (JAMESON, 1984, p. 27), contrariando, propriamente, as ideias de gênese, de progresso, de iluminismo. $O$ autor sugere, na recusa de um olhar apocalíptico, que a ideia é mais bem aceita se entendida como uma ruptura ou coupure, comumente relacionada ao enfraquecimento, rejeição ideológica e/ou estética ao movimento moderno, que se exaure nas produções surgidas durante o alto modernismo ${ }^{2}$. Ainda na perspectiva de Jameson (1984), o surgimento e solidificação de movimentos como a pop art; o fotorrealismo; o novo expressionismo; a ruptura da fronteira entre o clássico e o popular, principal característica da pós-modernidade, percebida nas composições de Phil Glass e Terry Riley, e, sobretudo, na arquitetura; o punk rock; a new wave; o cinema experimental; o nouveau roman; a nova crítica literária; e a nova estética da textualidade, entre outros, anunciam a chegada do que podemos chamar de pós-moderno. No bojo dessa questão, é oportuno mencionar que a transposição de fronteiras, quer sejam metafóricas, quer sejam territoriais, geográficas, parece bastante comum à pós-modernidade, porque esta aflora como um novo tempo constituído por paisagens horizontais compostas por ecletismos e divagações que decorem dessas ações transcendentes.

Com efeito, a pós-modernidade é cerceada por uma perspectiva desconstrutivista, para fazer uso de um conceito derridiano. Em $A$ Condição Pós-moderna, Jean-François Lyotard (2002, p. 15) explica que o pósmoderno configura-se como o estado em que a cultura se encontra após as transformações que modificaram as regras dos jogos circunscritos à ciência, à literatura e às artes, a contar do século XIX. Para ele, as mudanças ocorridas nas sociedades durante os últimos cinquenta anos têm ocasionado uma deslegitimação ao saber científico ou a qualquer discurso que propunha a formação de "consensos universais" estabelecidos pelo ideal iluminista, dando lugar, assim, ao surgimento de novas concepções estético-discursivas. Nesse sentido, a lógica pós-moderna se insere sob um sistema diverso, multifacetado, promovendo uma transfiguração histórico-geográfica, isto é, uma desestabilização de um '"tempo-espaço' com estrutura, um

2 Conforme sugere Jameson (1984), o período é marcado por manifestações estéticas como o expressionismo; existencialismo em filosofia; últimas representações do romance; a escola modernista na poesia; os filmes dos grandes autores. 
'tempo-espaço' rijo, sólido, durável" (BAUMAN, 1998, p. 110, itálico do autor) percebido na modernidade.

No que toca à lógica espacial, Gilles Deleuze e Félix Guattari, em Mil Platôs: capitalismo e esquizofrenia (1997), fazem uso de metáforas a fim de comparar os espaços modernos e pós-modernos. Para eles, este se estabelece como um espaço liso, nômade, isento de demarcações. Aquele, antagonicamente, como um espaço "estriado", composto por um tecido de tramas verticais e horizontais, bem delimitado e fixo. Fato dado, os autores sinalizam que a pós-modernidade acaba por suplantar a fixidez de que a modernidade dispunha. Vale mencionar que a definição de modernidade, também, é vacilante, uma vez que, da própria "reflexão sobre o processo acelerado de uma revolução histórica da arte e do gosto, pode surgir agora uma consciência de modernidade que, no final, define-se tão somente por oposição a si mesma" (JAUSS, 1996, p. 76). Deste feito, a modernidade, que ora pode ser vista como uma "estrutura sólida", também, pode ser percebida por uma base de especificidades cambiantes.

Corroborando a ideia de Lyotard e, ainda, objetivando explicitar a noção de pós-modernidade, Terry Eagleton $(1998$, p. 7) soma ao afirmar que ela se configura como uma linha de "pensamento que questiona as noções clássicas de verdade, razão, identidade e objetividade, a ideia de progresso ou emancipação universal, os sistemas únicos, as grandes narrativas ou os fundamentos definitivos de explicação", tais como "racionalismo, positivismo, tecnocentrismo, logocentrismo, crença no progresso linear, nas verdades absolutas, nas instituições" (PERRONE-MOISÉS, 1998, p. 182183), questões estas empreendidas durante a Era Moderna.

No que tange à literatura pós-moderna, esta, bem como o pós-modernismo - estilo - e a pós-modernidade - estrutura -, também, é um conceito difícil de precisar. Marcado por especificidades como a fragmentação; narradores controversos; superficialidade, o termo literatura pós-moderna é usado para descrever as produções literárias surgidas após a Segunda Guerra Mundial, configurando-se como uma reação às ideias iluministas subjacentes à literatura modernista.

Como é sabido, "não há ato de criação que não seja trans-histórico" (DELEUZE; GUATTARI, 1997, p. 83). Dessa forma, o entendimento da literatura, ou de qualquer outra Arte, sempre se dá na evidenciação 
do que existiu outrora. Para David Harvey (2008), a modernidade, e, consequentemente, a literatura moderna, primeiramente, determina-se pela construção de um mito, de um herói. O autor explica, ainda, que estes, que se estabelecem como figuras ontológicas, determinam os diferentes arquétipos do que é a modernidade nos anos que se seguem.

Na pós-modernidade, a literatura, constata-se, é sublinhada pelo desuso do que Lyotard (2002) caracteriza como dispositivo metanarrativo, dessa forma:

A função narrativa perde seus grandes atores (functeurs), os grandes heróis, os grandes perigos, os grandes périplos e os grandes objetivos. Ela se dispersa em nuvens de elementos de linguagem narrativos, mas também denotativos, prescritivos, descritivos etc., cada um veiculando consigo validades pragmáticas sui generis. (LYOTARD, 2002, p. 16, itálico do autor).

Tais especificidades descritas acima conferiam às produções literárias uma certa unicidade representativa. No tocante a este caráter uno, substanciado pelos esforços hercúleos dos heróis, Harvey $(2008$, p. 36) explica que essa noção começou a definhar a contar de 1848. Em vista disso, "a fixidez categórica do pensamento iluminista foi crescentemente contestada e terminou por ser substituída por uma ênfase em sistemas divergentes de representação" (HARVEY, 2008, p. 36). Desse modo, há uma reinserção de novos discursos, de novas estruturas idiomáticas, de novos tipos sociais. Há, ainda, uma (re)afirmação de questões relacionadas ao gênero, à etnia, à classe social, à religião, uma vez que, com a "decomposição dos grandes relatos" (LYOTARD, 2002, p. 28), a sociedade necessita de diferentes formas de representação, pois se percebe em uma realidade diferente da vivenciada na Era Moderna.

\section{a literatura Dós-moderna de luiz ruffato: breves reflexões}

A ficção brasileira atual, escreveu Manuel da Costa Pinto (2004), contempla, no mais das vezes, os centros urbanos. São temas dessas produções as "ruas deterioradas, botecos esquálidos, casas traumatizadas pelo desemprego, pela violência e pela loucura, -, há uma percepção geral do isolamento e da vulnerabilidade do sujeito moderno (e urbano)" (PINTO, 2004, p. 83). 
Essas especificidades são perceptíveis em Estive em Lisboa e Lembrei de Você (2009), e além, também, são encontradas em Eles Eram Muitos Cavalos (2001) que, igualmente, é de autoria de Luiz Ruffato. Como exemplo, segue um trecho da narrativa:

[...] Neon vaga veloz por sobre o asfalto irregular, ignorando ressaltos, lombadas, regos, buracos, saliências, costelas, seixos, negra nesga na noite negra, aprisionada, a música hipnótica, tum-tum tum-tum, rege o tronco que trança, tum-tum tumtum, sensuais as mãos deslizam no couro do volante, tum-tum tum-tum, o corpo, o carro, avançam, abduzem as luzes que luzem à esquerda à direita, um anel comprado na Portobello Road, satélite no dedo médio direito, tum-tum tum-tum, o bólido zune na direção do aeroporto de Cumbica, ao contrário cruzam faróis de ônibus que convergem de toda parte. (RUFFATO, 2001, p. 11).

Eles Eram Muitos Cavalos (2001) é ambientada em São Paulo e, desvendando a fugacidade da metrópole, traz à baila a vida de tipos sociais profusos que se entrecruzam: vendedores autônomos; mendigos; empregadas domésticas; prostitutas de luxo; traficantes. Os personagens, se é que podem ser classificados como tal, pois o livro é constituído por seres incógnitos, não nominados, dão vazão à materialização de uma narrativa simbiótica, que mistura diferentes gêneros literários (poesia, cartas, contos etc.), caracterizando um sinuoso ecletismo para esmo da segmentação.

De acordo com as ideias de Harvey (2008, p. 49), "os críticos literários 'modernistas' [...] têm a tendência de ver as obras como exemplos de um 'gênero' e de julgá-las a partir do 'código mestre' que prevalece dentro da 'fronteira' do gênero", isto é, o gênero de determinado veículo discursivo, embora constituído por um hibridismo estilístico, é detectável. Já a natureza pós-moderna, continua o mesmo autor, "consiste em ver a obra como um 'texto' com sua 'retórica' e seu 'idioleto' particulares, mas que, em princípio, pode ser comparado com qualquer outro texto de qualquer espécie" (HARVEY, 2008, p. 49). O que é possível constatar na produção literária de Ruffato.

De volta às ideias formuladas por Pinto (2004), até os anos 50, o Brasil dispunha de um imaginário rural. É a posteriori, pois, que esse tipo de ficção, que tem como lócus privilegiado a área urbana, emerge. Fase esta em que a renovação se estabelecia como prescrição. Assim, muitos autores brasileiros, 
nutridos por um sentimento de modernização, objetivavam a criação de uma "identidade nacional". A fim de melhor explicitar esta noção, as palavras do autor referido se fazem necessárias:

Quando essa modernização entrou em rota de naufrágio, a problemática realidade urbana eclodiu como uma experiência ao mesmo tempo incontornável e irredimível, passando a ser o habitat predominante na literatura brasileira a partir dos anos 6o. (PINTO, 2004, p. 83).

Na concepção do autor supracitado, a literatura brasileira contemporânea, apesar de afinada à retratação do espaço urbano, dispõe de uma variedade estética que está, diretamente, ligada à cultura na qual o escritor está inserido, uma vez que a ideia quer seja de pluralidades de destinos, quer seja de uma liberdade individual é, também, uma "construção cultural que nasce com a cidade e se materializa em formas literárias que transitam entre os registros memorialístico, realista, metafísico, escatológico, fantástico e satírico" (PINTO, 2004, p. 84).

Desse modo, a literatura brasileira atual, quase sempre, se caracteriza por uma mistura de tendências, pela confluência do "culto" e do popular, por uma temática cotidiana, por recursos gráfico-sonoros inovadores etc. Uma vez que a sociedade passa por uma ressignificação axiológica, a literatura, também, transmuta-se; originando-se, assim, de uma estética cultural que se estabelece à guisa do fragmentário, do efêmero, do diversificado.

\section{para além da fronteira: uma leitura do romance estive em lisboa e Iembrei de você, de luiz, ruffato, sob a ótica pós-modernista}

Narrado em primeira pessoa, Estive em Lisboa e Lembrei de Você (2009) traz à luz a história de Sérgio de Souza Sampaio, o Serginho. Este, a partir de um discurso trivial, mas frenético, que, além do falar mineiro, subjaz a própria velocidade comum ao lócus urbano, conta as suas aventuras "arrivistas" (BAUMAN, 1998) em espaços demasiado díspares, a saber: Cataguases, Minas Gerais, e Lisboa, Portugal. 
Contrapondo-se às narrativas epopeicas, ditas totalizantes, a literatura contemporânea é sublinhada pela mobilidade espacial, pelas identidades fragmentadas e pela desconstrução de conceitos universalistas. Integrando a coleção Amores Expressos 3 , o romance ora analisado eclode a partir do "surgimento de diversas propostas de livros escritos sob encomenda" (SCHOLLHAMMER, 2009, p. 113). Estive em Lisboa e Lembrei de Você (2009) propõe uma história que, para além da distância geográfica entre Cataguases e Lisboa, expressada a partir da linguagem diferenciada, do excesso de vírgulas, das reflexões vulgares, traz implícito a ruptura do elo fronteiriço entre o local e o global, entre o culto e o popular.

A era pós-moderna, conforme sugere Lyotard (2002), se voltou às pequenas narrativas. Assim, explica o mesmo autor, a história representada passa a ser a história da vida cotidiana, bem como dos grupos socialmente marginalizados, o que é possível perceber na obra de Ruffato. Estruturado em duas partes, Como Parei de Fumar e Como Voltei a Fumar, Estive em Lisboa e Lembrei de Você (2009) é um romance repleto de trivialidades e contado por um tipo comum, um trabalhador urbano, carente de bens de necessidades e de maiores oportunidades.

Na primeira parte da narrativa, Serginho evidencia as suas dificuldades diárias ainda no Brasil, no interior mineiro, mais precisamente. Diante dos males ofertados pelo vício, ele afirma ter tentado parar de fumar ao menos três vezes, conseguindo o feito somente após ter buscado ajuda profissional de Dr. Fernando, médico da empresa em que trabalhava. Este, prescrevendo o tratamento, - "tegretol, fluoxetina e adesivos de nicotina -, alertou, 'Os medicamentos auxiliam', mas parar mesmo, de vez, condiciona [...] determinação" (RUFFATO, 2009, p. 15). Nesta seção do livro, o narradorpersonagem coleciona reveses: o falecimento de sua mãe, dona Zizinha; o casamento malsucedido com a Noemi, uma jovem de "ideia fraca"; o desemprego "cinco-seis meses depois do passamento da pranteada mãe" (RUFFATO, 2009, p. 25); a perda da guarda do filho, o pequeno Pierre. Serginho credita todas as maledicências ocorridas em sua vida ao ato de parar de fumar, talvez porque, sem a fumaça que embaçava sua vida ínfima, a realidade lhe fosse, então, perceptível.

3 O projeto "convida autores a realizar viagens a lugares exóticos ou não tão exóticos e assumirem o compromisso de manter um blog da experiência e escrever um livro de ficção - uma história de amor no cenário da viagem" (SCHOLLHAMMER, 2009, p. 113). 
A existência do desafortunado narrador-personagem é marcada pelo "hedonismo", por um "reclamo de prazer, [...] e sempre mais aprazível prazer" (BAUMAN, 1998, p. 9), o que parece um artifício plasmador de sua própria realidade vil. Ao abandonar o cigarro, cujas características: "maço preto, caligrafia dourada", se faziam amenas ao consumo e ao prazer estético mercadológico, Serginho, procurou refúgio na bebida, negociando, assim, uma garrafa de Cavalo Branco, "que dizem, é o melhor vísque que existe" (RUFFATO, 2009, p. 20). Na perspectiva de Eagleton (1998, p. 127), as sociedades capitalistas contemporâneas se dão pelo antagonismo, elas são, igualmente, "libertárias e autoritárias; hedonistas e repressoras. O repreendido, geralmente excluído desde cedo, vive marginalizado na periferia e caminha [...] em busca do prazer do consumo".

A cultura pós-moderna traz consigo a efemeridade que, além do giro, do consumo cada vez mais rápido de mercadorias, do desapego a espaços e a contextos culturais, se estende às relações interpessoais. Isso pode ser observado na narrativa contemporânea de Ruffato. Em tom confidencial, Serginho afirma estar condicionado a uma série de relacionamentos instáveis, passadiços:

Quando apenas namorei, amadoristicamente [...]: Josélia, operária da Industrial, e Selene, da Manufatora; Ana Clara, colega da Pagadoria, desquitada; Kátia e Maíra, balconistas na rua da Estação; Silvana, Kênia e Lídice, estudantes de letras da Fafic [...]; Mariana e Janaína, professoras, uma primária, outra secundária; Zilma, cabeleireira (casada, fato por mim desconhecido e sinceramente deplorado); Verônica, auxiliar de enfermagem; Leda, caixa-de-banco, encostada no INSS, problema de coluna; Bia, que mexia com enfeites de biscuí; Irineia, proprietária de uma banca-de-camelô, [...], e Bete, que olhava pessoas doentes. (RUFFATO, 2009, p. 22).

A partir do excerto, pressupõe-se que as relações de amor do personagem se estabelecem pela transitoriedade. "O correlato cultural desse processo é o descartar o envolvimento romântico do amor erótico" (BAUMAN, 1998, p. 183). Desta forma, as relações são lépidas, não havendo lugar para compromissos duráveis. O resultado disso, presume-se, é o "rápido definhamento das relações humanas, despindo-as de intimidade e emotividade" (BAUMAN, 1998, p. 186). A rápida rotura dos laços afetivos 
de Serginho nos direciona, ainda, para outro aspecto comum à atualidade, 0 qual Jameson (1984) chamou de falta de profundidade, percebido nas produções literárias, nos objetos artísticose, consequentemente, nas relações humanas. Como sendo um conceito dual, o seu oposto é a superficialidade.

De todos os relacionamentos vivenciados (ou experimentados?) por Serginho, "engravidou justo a Noemi, do-lar, vizinha nossa, malfalada no bairro, que engraçou comigo quando finalmente consegui trocar a Biz por uma 125 retirada novinha em folha [...], filha do seu Ponté Carvalho, caboclo das-antigas" (RUFFATO, 2009, p. 22). O sogro, com base nos seus próprios costumes inveterados, fez Serginho casar-se com a filha sob duras ameaças, e:

Decorre que sagrou esta uma melancólica união desde a raiz, festança deproporcionada no Clube Aexas não sei para quantas cabeças, por gosto dos Carvalhos, gente de comer taboia e arrotar pernil, multidão reclamosa, a cerveja e o guaraná, quentes; os espetinhos de churrasco, passados; a maionese, desandada; a música, alta (pros idosos), cafona, (pra mocidade); as balas-de-coco, o bolo, minguados, [...]; o local, afastado; a noiva, xexelenta (no parecer dos meus); o noivo, otário (no juízo de todos). (RUFFATO, 2009, p. 23, itálicos do autor).

A Semírames ainda cercou Stela, minha cunhada, para tirar satisfação, e o troço ferveu quando acusou a vigarice dela, que adiantava dinheiro pros aposentados e, no dia do pagamento, [...], cobrar vinte por cento de juros e assessoria jurídica, só porque propalava, era doutora-advogada estudada e formada em curso de fim de semana em Juiz de Fora, mas nunca exibiu a carteirinha da OAB, "Ô porqueira de gente você se meteu". (RUFFATO, 2009, p. 25).

Como mostram os trechos acima, todo o envolto de Serginho é repleto de uma "presença real da falsidade garantida pela organização da aparência" (DEBORD, 1997, p. 140), a começar pelo sentimento que ele não nutria pela noiva. Na pós-modernidade, a espetacularização é determinante, sendo, então, a "principal produção da sociedade atual" (DEBORD, 1997, p. 17). Para além da criação de imagens, da sociedade que se expressa por meios comunicativos: publicidade; propaganda etc., Debord (1997) chama atenção para uma vida social marcada pelo acúmulo, o que acaba gerando um resvalo do ter para o parecer ter, tão comum ao nosso tempo. 
Desiludido, a ideia da viagem a Portugal surgiu a partir de uma conversa informal, de bar, em que o seu Oliveira inquire um destino e, Serginho, na ânsia de um progresso, de ser visto, de ser lembrado por grandes feitos, acata. Sem muitas digressões, a narrativa parece fixar-se no presente do protagonista. Mas, ele, diante de tantas dificuldades, planeja um futuro abastado nas terras lusitanas:

Quando me perguntaram "O quê que você vai fazer da vida agora, ô Serginho", que cismava em ir embora, "Pro estrangeiro", e, antes que debochassem, o seu Oliveira, pano-de-prato no ombro, destampou outra cerveja e apoiou o intento, "O caminho é Portugal", e, diante da admirada plateia, decantou as maravilhas do país pra onde todo mundo estava seguindo, e que, se mais novo, até mesmo ele voltava. (RUFFATO, 2009, p. 26).

"O momento é de reconstrução", dinheiro não é problema, falta mão-deobra, e os portugueses andam assoberbados, 'Escolhendo serviço', e sobram oportunidades para os brasileiros e pros pretos (que é como eles chamam as pessoas de cor), e perguntei, simulando desinteresse, quais profissões nossos patrícios desempenhavam por aquelas bandas, no que enfileirou pedreiro, bombeiro, eletricista, ladrilheiro, pinto-de-parede, motorista, garçom (os homens), arrumadeira, atendente de loja, manicure, cabeleireira, tomadeira-de-contade-criança e garçonete (as mulheres), com a vantagem de receber o salário em euro, "O lugar certo" pra quem não tem alergia a trabalho, e peguei matutando, caramba, [...], "Eu vou é pra Portugal". (RUFFATO, 2009, p. 26).

Assim como o personagem mineiro, Serginho, os sujeitos, sem perspectiva, na pós-modernidade, partem porque "quanto mais é depreciado o espaço, [...], mais obsessivamente as pessoas traçam e deslocam fronteiras" (BAUMAN, 2008, p. 75). Partem por achar "o lar maçante ou não suficientemente atrativo, demasiadamente familiar e contendo poucas surpresas" (BAUMAN, 1998, p. 116).

Outro ponto digno de observação é que Serginho, à maneira de um tipo módico, recluso em um ambiente interiorano, parece desconhecer os trâmites que constituem as sociedades. Inquirindo seu Oliveira, o personagem imigrante ficou a par do que precisava saber para realizar a viagem, como é possível constatar no trecho a seguir: 
"Como é que o sujeito chega em Portugal?", "De avião, ora pois", "Como é que é um avião por dentro?", "Apertado", "De onde sai o avião?", "Do Rio de Janeiro", "Quanto tempo demora a ida?", "Umas nove horas", "E a volta?", "Mesma coisa, ora pois", "Tem banheiro?", "Evidentemente", "Dá para dormir?", "Até ronco", "Tem comida?", "A da TAP é boa", "E o país?", "O melhor lugar do mundo", "Onde um sujeito que quiser ir, compra a passagem?", "Em Juiz de Fora", "Quanto custa mais ou menos?", "Uns mil dólares, dependendo da época", "Mil dólares", "Dependendo da época?", "Que mais um sujeito que quiser ir precisa saber?", "Tem que tirar passaporte...", "Passaporte?", "Um documento universal", "Hum...", "E tem que rocar o dinheiro", "Onde o sujeito arruma o tal passaporte?", "Na Polícia Federal, em Juiz de Fora", "E o quê que o senhor falou de dinheiro?", "Tem que trocar, levar euro", "E se o sujeito nem nunca viu um euro de perto?", "Guardo comigo umas notas, posso mostrar". (RUFFATO, 2009, p. 29).

Os trechos elencados acima testemunham que o escritor mineiro dá vida a um personagem-protagonista desadornado, leigo. Ruffato, ao compor uma narrativa leve, carregada de comicidade e de um tom demasiado regionalista, atinge uma postura estética diversificada, a fim de construir um sentido que sobrepõe o discurso narrativo, chamando atenção, pois, para um conjunto idiossincrático local.

Outrossim, a notícia da ida de Serginho a Portugal gerou burburinho, e, então, o assunto logo vulgarizou. Ele, que se tornou importante com a ideia da viagem internacional, desfilava "em direção à redação do jornal Cataguases, órgão oficial do município" (RUFFATO, 2009, p. 32, itálico do autor), local em que a notícia chegava via telefone e/ou computador. 0 interesse em torno da vida do personagem nos propõe uma reflexão acerca da nossa própria realidade, ainda que a literatura não tenha especificidade apriorística e, tampouco, compromisso com o real. Para Schollhammer (2009, p. 56), o que mais interessa à mídia de hoje é a "'vida real'. Notícias em tempo real, reportagens diretas, câmera oculta a serviço do furo jornalístico ou do mero entretenimento, televisão interativa, reality shows, entrevistas, programas de auditório". Na concepção de Jameson (1984), as transformações tecnológicas afluem acompanhadas de uma influência que muda o estatuto social, porque o influencia diretamente. Para Debord (1997), dentre os princípios fundamentais da técnica está o isolamento, mas, também, a alienação, em que os sujeitos, os espectadores, melhor 
dizendo, se reconhecem nas imagens apresentadas, e, assim, no que se refere ao "homem que age, a exterioridade do espetáculo aparece no fato de seus próprios gestos já não serem seus, mas de um outro que os representa por ele" (DEBORD, 1997, p. 24). Dessa maneira, a TV, o telefone e o computador são os dispositivos mantenedores dos estilos de vida na contemporaneidade, cujo fundamento substancial, na maioria das vezes, é a aparência.

A promessa de um contato por parte de seu Oliveira fez Serginho chegar a Portugal com umas economias decorrentes da venda da casa que ele e a irmã, Samírames, herdaram da falecida mãe. Para Ivan Cachorro Doido, amigo de Serginho, Portugal, ao contrário de Cataguases, representava a civilização, a alta cultura e, depois de tê-la conhecido, o imigrante não mais iria aturar "o povo da Taquara Preta, sem educação, sem modos nem compostura, desclassificado" (RUFFATO, 2009, p. 33). Para além da fronteira geográfica, a transposição almejada por Serginho fora, sempre, concernente à sua condição enquanto sujeito social. Ele objetiva grandes feitos, ser aceito, ganhar dinheiro, investir em "imóveis em Cataguases, garantir uma velhice tranquila, de papo-pro-ar" (RUFFATO, 2009, p. 29), assegurar o futuro do menino Pierre e, ainda, manter as obrigações "maritais", como o pagamento de pensão ao, ainda pequeno, Pierre, e à esposa, internada em uma clínica psiquiátrica. E, por isso, ele imigra para Portugal.

Como Voltei a Fumar intitula a segunda parte do livro, em que Serginho narra a sua chegada e estadia no país europeu. Hospedado, preliminarmente, no Hotel do Vizeu, na Madragoa, um bairro antigo, a primeira impressão do imigrante brasileiro é de estranhamento:

Um bairro antigo pra caramba, de ruinhas estreitas, casario maquiado, uma antiguidade tão grande que até as pessoas são passadas, velhas agasalhada em xailes pretos, velhos de boinas de lã subindo-descendo devagar o ladeirame, sem ar, escorados nas paredes, gente extravagante que parece uma noite deitou jovem e acordou, dia seguinte, idosa, cheia de macacoa, vista fraca, junta dolorida, dente molengo, perna inchada, e, assustados, passaram a desconfiar de tudo, sempre enfezados, resmungando pra dentro, respondendo as perguntas com irritação, e, quando pus o pés em Lisboa, o rapaz olhou o retrato no passaporte, falei bom dia, nem respondeu, bateu um carrinho e mandou seguir, e já fui desgostando desse sistema, pensei comigo que ele não deveria estar bem dos bofes [...] (RUFFATO, 2009, p. 39, negrito do autor). 
Como um "arrivista, alguém já no lugar mas não inteiramente do lugar" (BAUMAN, 1998, p. 92), Serginho é "um aspirante a residente sem permissão de residência" (1998, p. 92), pois é, no dizer dele, excomungado, esconjurado pelos patrícios que o viam a andar pelas terras lusitanas. Nesse sentido, ele vive buscando se estabelecer numa nação que lhe é alheia, e se adequar a costumes que, nem de longe, são seus, apesar de afinado por uma ilusão identitária, ilustrada a partir da hibridização, isto é, de uma confluência cultural de dialetos lusitanos, inseridos na obra em negritos, como é perceptível no trecho supracitado. Entretanto, apesar das dificuldades e diferenciações existentes, Serginho era movido por um desejo de pertencimento a Lisboa.

Um outro aspecto meritório de nota diz respeito à estrutura sintática do trecho acima, mais precisamente no que diz "gente extravagante que parece uma noite deitou jovem e acordou, dia seguinte, idosa" (RUFFATO, 2009, p. 39). Nele, há um predomínio de "períodos curtos, justaposição, frases incompletas (as chamadas frases mínimas, suficientes para a compreensão do ouvinte e que se interrompem quando isso acontece), baixa ocorrência de subordinação [...]" (PRETI, 2008, p. 3), que se estabelecem como uma expressão estética, à luz da fragmentação pós-moderna, usada para o fim que o autor deseja alcançar. Desse modo, em muitas narrativas contemporâneas, tudo é "efeito de uma linguagem que reproduz mimeticamente o movimento de deslocamento, de fuga. [...] seja qual for o livro, o protagonista é invariavelmente um ser errante [...] que, ao buscar o exílio, encontra cárceres renovados" (PINTO, 2004, p. 118-119).

O narrador-personagem sai à procura de uma pensão barata para se estabelecer, quando localiza a do seu Seabra, que "exigiu pagamento adiantado". Diante de incontáveis dificuldades: de encontrar o contato do seu Oliveira; de estabelecer uma relação amistosa com os portugueses, o conforto lhe chega ao deparar-se com um colega que, igualmente a ele, é brasileiro:

[...] e, muito depois, expondo essa história pro Jerê, colega brasileiro que ganha a vida tocando violão e cantando num bar da praia de São João do Estoril, [...], ele, sujeito viajado, que até a Espanha conhece, comentou que esse lugar existe sim, mas fica perto do cais do Porto, cidade do norte do país [...], e, apatetado, recuperei o seu oliveira pro meu rol de pessoas dignas, ele que, por uma data, 
frequentou o inferno, e acho mesmo que até saiu de lá meio sapecado, o coitado (RUFFATO, 2009, p. 44).

As noites incendiavam meu estômago vazio, estumando a vigília, eu escutava a barulhama do assoalho veterano e rinchador, e me vinha à cabeça o destino do Baptista Bernardo, vizinho de parede, escravo de uma muleta compensatória da perna esquerda, que deparava, de vez em quando, a desoras, ninando o casalzinho de filhos que ressonava num edredão estendido atrás da poltrona, onde, sentado, os fones do uálquemen pendurados nas orelhas, ouvia, autista, a kizomba, a música lá-deles, e especulei do seu Carrilho se o angolano e a mulher desentendiam muito, e ele, respondendo "Ao contrário, vivem bem", ficou abestalhado com minha cegueira, todos sabiam que, quando o Baptista Bernardo refugiava lá embaixo com as crianças, é porque tinha arranjado freguês pra mulher, uma africana alta, magra e sorridente, conhecida minha de bons-dias, e abismado perguntei como alguém pode sequer pensar em alugar a própria esposa, e seu Carrilho, filosofando, "É a miséria, filho, a miséria". (RUFFATO, 2009, p. 53-54, itálico e negritos do autor).

Os recortes explicitam que os primeiros dias nas terras lusitanas serviram para mostrar a Serginho que as adversidades o perseguiam de maneira contínua, independentemente do espaço em que ele se encontrava: Cataguases ou Lisboa, pois em ambos os contextos, o personagemprotagonista vivia à margem.

Para além disso, vale chamar a atenção para a pluralidade de identidades nacionais contidas no romance, especialmente na segunda parte da narrativa. Assim, convém ressaltar que, na pós-modernidade, os sujeitos se deslocam e se confrontam em decorrência da globalização, como explica Stuart Hall (1992). Há, nesse sentido, um choque cultural ocasionado por especificidades antitéticas. Para Eagleton (1998), a pós-modernidade confirma o mundo como contingente, gratuito, diverso, instável, imprevisível, um conjunto de culturas ou interpretações desunificadas. Entretanto, apesar das diferenças culturais, latino-americanas, europeias e africanas, Serginho e o angolano Baptista Bernardo tinham muito em comum: ambos saíram de suas nações de origem, ambos buscavam melhores condições de vida, fatos que são ilustrados a partir dos grandes esforços construtivos de abandonar o lar, os familiares e migrar rumo ao desconhecido. 
Outrossim, a vida relatada nas histórias de Ruffato "é uma vida oprimida, inumana, mesquinha, miserável e cheia de violência nas relações sociais e nas relações mais íntimas" (SCHOLLHAMMER, 2009, p. 85). De repente, com a demissão do trabalho de garçom, devido à aparência, à ignorância em relação às línguas estrangeiras, a cidade já não se faz mais tão atrativa ao narrador.

Ao passear pela cidade, Serginho atenta-se às particularidades da terra lusitana: "Lisboa cheira sardinha no calor e castanha assada no frio, descobri isso revirando a cidade de cabeça-pra-baixo, de metrô, de eléctro, de autocarro, de comboio, de a-pé, sozinho ou ladeado pela Sheila" (RUFFATO, 2009, p. 67, negritos do autor). Com efeito, em meio a tantos descontentamentos, conforme observaram Tânia Regina Oliveira Ramos e Amanda Cadore (2010, p. 151), pesquisadoras de literatura brasileira contemporânea, o narrador-personagem, "desterritorializado, encontra o Brasil em Sheila, uma prostituta brasileira, gentil e receptiva. Nela deposita a esperança do retorno às raízes, de estar mais perto da pátria". Como tudo na vida do personagem protagonista, Sheila torna-se mais um caso malsucedido para o imigrante brasileiro.

A fim de conferir sentido ao título do romance Estive em Lisboa e Lembrei de Você (2009), é producente explicitar que as dificuldades em terras estrangeiras fazem com que Serginho retorne, mnemonicamente, ao lar, à pátria, aos familiares, como é evidenciado no trecho abaixo:

[...] e, comovido, ajoelhei e recordei a finada minha mãe, o finado meu pai, o Pierre, os amigos e parentes agora tão distantes, e clamei pra que Deus auxiliasse aquele momento difícil de solidão e arrependimento, que Ele providenciasse logo uma colocação, porque o dinheiro escasseava, mal dava pra bancar o aluguel do quarto e o almoço, minha única refeição, rifados o café-damanhã e a janta, por demanda de economia, [...] (RUFFATO, 2009, p. 53-54).

A narrativa parece atar as duas pontas constitutivas da história, da vida de Serginho que, entre Amores Expressos ${ }^{4}$, no sentido mais apriorístico que

4 Coleção Amores expressos - Editora Companhia das Letras. "Alguns escritores brasileiros ganharam uma 'bolsa' (optamos por esta imagem porque é bastante adequada ao projeto que pressupõe bagagem material e cultural) e viajaram para diferentes cidades do mundo para buscar inspiração e escrever uma história de amor: amores expressos, na ambiguidade plena do 
a última palavra carrega: o que é feito para ser rapidamente consumido, experimentado, enviado, deve fidelidade àquele que jamais o abandonara, que estivera sempre lá, pronto para ser revisitado: o cigarro.

Com a perpetuação das dificuldades, com o abandono de Sheila, que levou embora as poucas economias arrecadadas e, seduzido pelos "prazeres verdadeiros ou imaginários de uma vida de quem acumula sensações" (BAUMAN, 1998, p. 117), o narrador confidencia-nos: "foi assim que, depois de seis anos e meio, pouco mais ou menos, entrei numa tabacaria, pedi um maço de SG, um isqueiro, tirei um cigarro, acendi e voltei a fumar" (RUFFATO, 2009, p. 83). O cigarro, nesse sentido, também, surge como metáfora memorialística ao que é enunciado no título da obra.

\section{consideracões finais}

Constituído por estruturas sintáticas triviais, o romance de Luiz Ruffato, como evidenciado acima, testemunha os diferentes estratos sociais, imbricados numa atmosfera pós-moderna e "desenraizados por uma força demasiadamente poderosa" (BAUMAN, 1998, p. 117), em que a sobrevivência e a readaptação em contextos socioculturais díspares se estabelecem de maneira cada vez mais comum.

As dificuldades vivenciadas por Serginho mostram que a Lisboa narrada pelo Seu Oliveira difere da que foi, por ele, encontrada, uma vez que identificação de imigrantes desalentados, sem lar, é algo comum na terra lusitana. Com efeito, ao personagem é conferida uma certa representatividade, porque ele materializa as diversas vozes de povos migrantes que, em situações análogas, deixam seus países de origem e se deslocam para terras estrangeiras em busca de melhores condições de vida.

No que toca às especificidades estéticas do romance, é perceptível que autores como Luiz Ruffato, conforme sugere Schollhammer (2009, p. 15), façam uso de uma escrita breve, fragmentária, como forma de contemplação do "real", que se evidencia na ótica de "uma reinvenção do realismo, à procura de um impacto numa determinada realidade social, ou na busca de se refazer a relação de responsabilidade e solidariedade com os problemas sociais e culturais de seu tempo". Schollhammer (2009) sugere, ainda, que

adjetivo expressos" (RAMOS; CADORE, 2010, p. 149). 
tal feito pode ser entendido como uma sutura entre a retratação do real e a forma com que ele é representado. Textos fragmentados para relações interpessoais e identidades fragmentadas. "Falta de profundidade" para vivências superficiais. Construções sintáticas ritmicamente velozes para a iminência do fugaz, isto é, do deslocamento trivial à pós-modernidade.

\section{referências}

BAUMAN, Zygmunt. O mal-estar da pós-modernidade. Rio de Janeiro: Jorge Zahar Ed., 1998.

- Globalização: as consequências humanas. Tradução de Marcus Penchel. Rio de Janeiro: Jorge Zahar, 1999.

. Modernidade Líquida. Rio de Janeiro: Jorge Zahar, 2001.

Amor Líquido - Sobre a fragilidade dos laços humanos. Tradução de Carlos Alberto Medeiros. Rio de Janeiro: Jorge Zahar, 2004.

A sociedade individualizada: vidas contadas e histórias vividas. Tradução de José Gradel. Rio de janeiro, 2008.

DEBORD, Guy. A Sociedade do Espetáculo: comentários sobre a sociedade do espetáculo. Tradução de Estela dos Santos Abreu. Rio de Janeiro: Contraponto, 1997.

DELEUZE, Gilles; GUATTARI, Félix. Mil Platôs: Capitalismo e Esquizofrenia. São Paulo: Editora 34, 1997. v. 5.

EAGLETON, Terry. As Ilusões do Pós-modernismo. Rio de Janeiro: Jorge Zahar, 1998. Tradução de Salma Tannus Muchail. São Paulo: n-1 Edições, $2013 a$.

HALL, Stuart. A identidade cultural na pós-modernidade. Tradução de Tomaz Tadeu da Silva, Guaracira Lopes Louro. Rio de Janeiro: DP\&A, 1992.

HARVEY, David. Condição Pós-Moderna. São Paulo: Edições Loyola, 1992.

JAMESON, Fredric. Pós-Modernismo: a lógica cultural do capitalismo tardio. São Paulo: Ática, 1984 
LYOTARD, Jean-François. A condição pós-moderna. Tradução de Ricardo Corrêa Barbosa. Rio de Janeiro: José Olympio, 2002.

PERRONE-MOISÉS, Leyla. Altas Literaturas: escolha e valor na obra crítica de escritores modernos. São Paulo: Companhia das Letras, 1998.

PINTO, Manuel da Costa. Literatura brasileira hoje. São Paulo: Publifolha, 2004 .

PRETI, Dino. A linguagem literária contemporânea no Brasil: a elaboração da oralidade. FronteiraZ - Revista do Programa de Estudos Pós-Graduados em Literatura e Crítica Literária, São Paulo, n. 2, p. 1-7, 2008. Disponível em: $<$ https://revistas.pucsp.br/fronteiraz/article/view/12591>. Data de acesso: 23 jul. 2019.

RAMOS, Tânia Regina Oliveira; CADORE, Amanda. Desamores expressos Estive em Lisboa e lembrei de você. Navegações, Porto Alegre, v. 3, n. 2, p. 149-153, jul./dez. 2010. Disponível em: <https://revistaseletronicas.pucrs.br/ ojs/index.php/navegacoes/article/view/8434>. Data de acesso: 25 ago. 2019.

RUFFATO, Luiz. Eles eram muitos cavalos. São Paulo: Boitempo, 2001. . Estive em Lisboa e lembrei de você. São Paulo: Companhia das Letras, 2009.

SCHOLLHAMMER, Karl Erik. Ficção brasileira contemporânea. Rio de Janeiro: Civilização Brasileira, 2009.

Artigo recebido em: 02/02/2020 Aceito em: 24/06/2020 